\title{
Evolution of Polycomb-group function in the green lineage
}

\section{[version 1; peer review: 2 approved]}

\section{Daniel Schubert (iD)}

Department of Biology, Epigenetics of Plants, Freie Universität Berlin, Berlin, Germany

V1 First published: 08 Mar 2019, 8(F1000 Faculty Rev):268

https://doi.org/10.12688/f1000research.16986.1

Latest published: 08 Mar 2019, 8(F1000 Faculty Rev):268

https://doi.org/10.12688/f1000research.16986.1

\section{Abstract}

Epigenetic gene regulation ensures the mitotically or meiotically stable heritability (or both) of gene expression or protein activity states and maintains repetitive element repression and cellular identities. The repressive Polycomb-group (PcG) proteins consist of several large complexes that control cellular memory by acting on chromatin and are antagonized by the Trithorax-group proteins. Especially, Polycomb repressive complex 2 (PRC2) is highly conserved in plants and animals but its function in unicellular eukaryotes and during land plant evolution is less understood. Additional PcG complexes and associated proteins are only partially conserved and have evolved in a lineage-specific manner. In this review, I will focus on recent advances in the understanding of PcG function in the green lineage and its contribution to land plant evolution.

\section{Keywords}

Polycomb, PRC2, phase transition, telomeres, H3K27me3, plant evolution

\section{Open Peer Review \\ Approval Status \\ 1 \\ 2 \\ version 1 \\ 08 Mar 2019 \\ Faculty Reviews are review articles written by the prestigious Members of Faculty Opinions. The articles are commissioned and peer reviewed before publication to ensure that the final, published version is comprehensive and accessible. The reviewers who approved the final version are listed with their names and affiliations. \\ 1. Yuehui He (iD), National Key Laboratory of Plant Molecular Genetics, Shanghai Center for Plant Stress Biology, CAS Center for Excellence in Molecular Plant Sciences, Chinese Academy of Sciences, Shanghai, China}

2. Rakesh K Mishra, Centre for Cellular and Molecular Biology, Hyderabad, India Any comments on the article can be found at the end of the article. 
Corresponding author: Daniel Schubert (dan.schubert@fu-berlin.de)

Author roles: Schubert D: Funding Acquisition, Writing - Original Draft Preparation

Competing interests: No competing interests were disclosed.

Grant information: Work in the author's laboratory is supported by the Deutsche Forschungsgemeinschaft (DFG) (CRC973, Project C7).

The funders had no role in study design, data collection and analysis, decision to publish, or preparation of the manuscript.

Copyright: $\odot 2019$ Schubert D. This is an open access article distributed under the terms of the Creative Commons Attribution License, which permits unrestricted use, distribution, and reproduction in any medium, provided the original work is properly cited.

How to cite this article: Schubert D. Evolution of Polycomb-group function in the green lineage [version 1; peer review: 2 approved] F1000Research 2019, 8(F1000 Faculty Rev):268 https://doi.org/10.12688/f1000research.16986.1

First published: 08 Mar 2019, 8(F1000 Faculty Rev):268 https://doi.org/10.12688/f1000research.16986.1 


\section{Introduction}

Polycomb-group (PcG) proteins maintain cellular and tissue identity in multicellular organisms and regulate phase transitions in plants ${ }^{1}$. As PcG orthologues are absent from Saccharomyces cerevisiae and Schizosaccharomyces pombe genomes, PcG function has long been thought to be nonessential in unicellular organisms. However, recent genomic analyses have identified orthologues and function of PcG genes in many unicellular organisms which may unravel their ancient function in genome regulation ${ }^{2}$. As more and more PcG-associated and clade-specific factors have been identified in the green lineage, particularly in embryophyta, PcG function can be studied in relation to land plant evolution and phase transitions occurring in these organisms.

PcG proteins assemble in several large complexes, the Polycomb repressive complexes (PRCs). Particularly, PRC2 subunits are highly conserved, even in some unicellular organisms, and mediate trimethylation of histone $\mathrm{H} 3$ lysine 27 (H3K27me3) $)^{3,4}$. PRC1, a Ring Finger E3 ligase complex which catalyzes the monoubiquitylation of histone $\mathrm{H} 2 \mathrm{~A}$, is also likely to be evolutionarily ancient as orthologues of its subunits are found in mammals, plants, insects, and other species but have been lost in more primitive organisms ${ }^{3-5}$. PcG proteins repress distinct elements in the genome, ranging from repetitive elements to developmental and stress responsive genes, and have a preference for repetitive elements in more primitive organisms and for genes in more complex organisms ${ }^{2,4-7}$.

Here, I will summarize recent advances in studying PcG function in the green lineage as exciting new analyses uncovered target genes, PcG recruitment factors, and function of $\mathrm{PcG}$ proteins in more primitive organisms. These studies shed light on the evolution of PcG function and their contribution to genome and developmental regulation. I do not cover all general aspects of PcG-mediated gene regulation as this has been extensively reviewed recently ${ }^{1,3}$.

\section{Conservation and function of Polycomb-group proteins}

Recent analyses have identified PRC2 orthologues and the presence of $\mathrm{H} 3 \mathrm{~K} 27 \mathrm{me} 2 / 3$ in various unicellular and primitive organisms such as ciliates (Tetrahymena thermophila), diatoms (Phaeodactylum tricornutum), filamentous fungi (Neurospora crassa), green algae (Chlamydomonas reinhardtii), and red algae (Cyanidioschizon merolae). Obvious orthologues of PRC1 are not present in the genomes of these organisms but are present only in higher animals (Bilateria) and emerged in land plants such as Marchantia polymorpha and Physcomitrella patens ${ }^{2,5-9}$, suggesting a function for PRC1 in controlling multicellularity or complex tissue organization or both. Generation of genomewide occupancy maps of the PRC2 mark H3K27me3 or knock-down analyses of PRC2 members (or both) revealed an important function for $\mathrm{PRC} 2$ in repressing repetitive elements and heterochromatic regions in the primitive organisms, whereas preferential gene-specific H3K27me3 occupancy is found in the moss $P$. patens and in the flowering plant Arabidopsis thaliana $^{10,11}$. Nevertheless, in all species examined, the presence of $\mathrm{H} 3 \mathrm{~K} 27 \mathrm{me} 3$ is correlated with low expression level on a genomic view. In addition, H3K27me3 occupies larger domains of multiple nucleosomes, which is required for its inheritance through cell division. In higher plants (Arabidopsis), the role of $\mathrm{H} 3 \mathrm{~K} 27 \mathrm{me} 3$ in heterochromatin and repetitive element regulation is likely substituted by additional epigenetic regulators such as ARABIDOPSIS TRITHORAX-RELATED PROTEIN 5 (ATXR5) and ATXR6, which mediate H3K27me $1^{12}$.

Importantly, studies in the moss Physcomitrella indicate that PRC2 became important to regulate phase transitions as PRC2 mutants display sporophytic traits in the haploid gametophytic phase ${ }^{13,14}$. In addition, PRC2 represses the evolutionarily conserved homeobox gene BELL1, a master regulator for the gametophyte-to-sporophyte transition in Physcomitrella ${ }^{15}$ and possibly its interaction partner $\mathrm{KNOX} 2$, which is an $\mathrm{H} 3 \mathrm{~K} 27 \mathrm{me} 3$ $\operatorname{target}^{11,16}$. As a KNOX protein and a BELL-related protein promote zygote formation in the haplontic alga Chlamydomonas and PRC2 is present in the Chlamydomonas genome ${ }^{17}$, it will be interesting to investigate whether PRC2 is also controlling phase transitions prior to the emergence of land plants.

Whereas the H3K27me3 "writer" PRC2 is widely conserved, the "reader" of H3K27me3 likely has evolved several times. The first H3K27me3 reader was identified in Drosophila as the chromodomain protein POLYCOMB which is probably conserved in most vertebrates and invertebrates ${ }^{18,19}$. In Arabidopsis, H3K27me3 recruits the related but not orthologous chromodomain protein LIKE HETEROCHROMATIN PROTEIN1 (LHP1) ${ }^{20,21}$; however, as lhpl mutants have a weak phenotype (in contrast to PRC2 knock-outs), it was hypothesized that additional Arabidopsis proteins have H3K27me3 binding capacity. Indeed, recently, the PHD-domain protein EARLY BOLTING IN SHORT DAYS (EBS) and SHORT LIFE (SHL) were shown to have overlapping function with LHP1 and "read" H3K27me3 $3^{22-24}$. Interestingly, the most ancient LHP1 homologues are found in land plants, such as M. polymorpha and Physcomitrella, similar to other PRC1 members ${ }^{9,25}$, whereas EBS and SHL are conserved in charophytic algae (such as Chara braunii) ${ }^{26}$ and possibly even in chlorophytic algae (such as Chlamydomonas and prasinophytes), suggesting specific inventions or requirements of PRC1 during land plant evolution.

\section{Recruitment of Polycomb-group proteins}

In Drosophila, recruitment of $\mathrm{PcG}$ proteins is mediated by Polycomb response elements (PREs), DNA elements which maintain gene repression but are diverse in sequence and evolutionarily not conserved ${ }^{3,27}$. In Arabidopsis, PRE-like elements have recently been identified, suggesting that also in plants a combination of diverse sequences and DNA-binding factors are involved in the recruitment of PcG proteins ${ }^{28,29}$. While PRC1 and PRC2 members do not possess DNA-binding motifs, VIVIPAROUS1/ ABI3-LIKE1 (VAL1) and VAL2, which are DNA sequencespecific binding factors, directly associate with specific DNA sequence elements of PcG target genes and bind to $\mathrm{H} 3 \mathrm{~K} 27 \mathrm{me} 3$ and PRC1 members ${ }^{30-32}$, suggesting that they are the longsought mediators between PcG proteins and DNA. Interestingly, similar to other PRC1 proteins, VAL proteins are highly conserved in the land plants Marchantia and Physcomitrella but are likely 
absent in charophytic algae ${ }^{25,26}$. A novel class of PcG target gene binding factors was recently identified by genetic screening in Arabidopsis, the telomere repeat-binding factors (TRBs) which regulate both telomeres and PcG target genes ${ }^{29,33,34}$. Interestingly, H3K27me3 is highly abundant at telomeres, including those of humans, Arabidopsis, the red algae C. merolae, and the fungus $N$. $\operatorname{crassa}^{5,7,35,36}$, indicating an ancient connection between telomeric sequences/telomeres and PcG recruitment. In Neurospora, short arrays of telomeric repeats are sufficient to recruit $\mathrm{PRC} 2 / \mathrm{H} 3 \mathrm{~K} 27 \mathrm{me} 3^{37}$. Telomeric repeat-containing RNAs (TERRAs) have been identified in various species, including humans and Arabidopsis ${ }^{38,39}$, and recently it was revealed that TERRAs bind to PRC2 in humans ${ }^{35}$. Whether this is a general principle is currently unclear; however, there is increasing evidence that telomeric repeats, either as DNA sequence or as transcript, are involved in recruitment of PcG proteins across kingdoms. It is likely that regulation of telomeres by PcG proteins is evolutionarily more ancient but has been adopted by acquisition of telomeric repeat sequences at genes to recruit PcG proteins.

Although TRB proteins bind to PRC2 members ${ }^{27}$, they are likely not permanently associated with PRC1 or PRC2 as TRB1 complex isolation analyses did not identify these proteins ${ }^{40}$. However, TRB1 likely forms a complex with PcG-associated proteins, ENHANCER OF POLYCOMB RELATED1/2 (EPCR1/2) and PWWP-DOMAIN INTERACTOR OF POLYCOMBS1 (PWO1) ${ }^{40,41}$. While PWO1 shows protein-protein and genetic interactions with PRC2 genes $^{41}$, the connection of EPCR1 with $\mathrm{PcG}$ is less clear, especially as these proteins, together with PWO1 and TRBs, also regulate heterochromatin silencing and telomere length ${ }^{40}$. Thus, these proteins and complexes likely have a more general role in chromatin silencing but may be important for stabilizing PcG silencing or creating a repressive environment.

\section{Conclusions}

Recent analyses, particularly in Arabidopsis, have resolved long-standing questions in $\mathrm{PcG}$ regulation in plants, including the isolation of novel $\mathrm{H} 3 \mathrm{~K} 27 \mathrm{me} 3$ readers and the identification of PRC1-like complexes and PRE-like recruitment elements. It is apparent that PRC2 has fundamental functions as it is highly conserved, even in unicellular eukaryotes. Although it targets and regulates repetitive elements and telomeric sequences in these species, it also targets genes which are largely not repressed but may be inducible upon environmental change or activated in a different phase of the life cycle. As PcG proteins regulate phase transitions in seed plants and mosses by controlling specific transcription factors and all of these factors are conserved in unicellular and multicellular algae, it is tempting to speculate that the transition from the haploid to the diploid phase (and vice versa) in these organisms is regulated by PcG. Thus, genetic analyses in these algae and primitive land plants such as Marchantia will be required to elucidate these questions.

While expression of $\mathrm{PcG}$ genes is largely not transcriptionally regulated, it will be interesting to reveal whether level or activity of these proteins is regulated post-transcriptionally in a developmental and responsive manner. Interestingly, a recent analysis of cold responses and circadian rhythms in Arabidopsis uncovered extensive alternative splicing of several PcG mRNAs likely leading to an altered PcG proteome ${ }^{42}$.

Overall, it will be highly interesting and rewarding to study PcG function in non-seed plants to learn about land plant evolution, regulation of phase transitions, the evolution of multicellularity and distinct cell types, and genome regulation in general. While plants have evolved novel innovations in relation to PcG function, the general principles and factors involved appear to be higher conserved than previously anticipated but are employed for different gene regulatory functions.

\section{Abbreviations}

ATXR,ARABIDOPSIS TRITHORAX-RELATEDPROTEIN;EBS, EARLY BOLTING IN SHORT DAYS; EPCR1/2, ENHANCER OF POLYCOMB RELATED1/2; H3K27me3, histone H3 lysine 27 trimethylation; PcG, Polycomb group; PRC, Polycomb repressive complex; PRE, Polycomb response element; PWO1, PWWP-DOMAIN INTERACTOR OF POLYCOMBS1; SHL, SHORT LIFE; TERRA, telomeric repeat-containing RNA; $\mathrm{TRB}$, telomere repeat-binding factor; VAL, VIVIPAROUS1/ ABI3-LIKE

\section{Grant information}

Work in the author's laboratory is supported by the Deutsche Forschungsgemeinschaft (DFG) (CRC973, Project C7).

The funders had no role in study design, data collection and analysis, decision to publish, or preparation of the manuscript.
1. Förderer A, Zhou Y, Turck F: The age of multiplexity: recruitment and interactions of Polycomb complexes in plants. Curr Opin Plant Biol. 2016; 29 169-78.

PubMed Abstract | Publisher Full Text

2. F Shaver S, Casas-Mollano JA, Cerny RL, et al:: Origin of the polycomb repressive complex 2 and gene silencing by an $E(z)$ homolog in the unicellular alga Chlamydomonas. Epigenetics. 2014; 5(4): 301-12. PubMed Abstract | Publisher Full Text | F1000 Recommendation
3. F Schuettengruber B, Bourbon HM, Di Croce L, et al.: Genome Regulation by Polycomb and Trithorax: 70 Years and Counting. Cell. 2017; 171(1): 34-57. PubMed Abstract | Publisher Full Text | F1000 Recommendation

4. $\quad F$ Mozgova I, Hennig L: The polycomb group protein regulatory network. Annu Rev Plant Biol. 2015; 66: 269-96.

PubMed Abstract | Publisher Full Text | F1000 Recommendation

5. Mikulski $\mathrm{P}$, Komarynets $\mathrm{O}$, Fachinelli $\mathrm{F}$, et al:: Characterization of the 
Polycomb-Group Mark H3K27me3 in Unicellular Algae. Front Plant Sci. 2017; 8: 607.

PubMed Abstract | Publisher Full Text | Free Full Text

6. $\quad F$ Liu Y, Taverna SD, Muratore TL, et al.: RNAi-dependent H3K27 methylation is required for heterochromatin formation and DNA elimination in Tetrahymena. Genes Dev. 2007: 21(12): 1530-45. PubMed Abstract | Publisher Full Text | Free Full Text | F1000 Recommendation

7. F Jamieson K, Rountree MR, Lewis ZA, et al:: Regional control of histone $\mathbf{H 3}$ lysine 27 methylation in Neurospora. Proc Natl Acad Sci U S A. 2013; 110(15): 6027-32.

PubMed Abstract | Publisher Full Text | Free Full Text | F1000 Recommendation

8. F Veluchamy A, Rastogi A, Lin X, et al:: An integrative analysis of posttranslational histone modifications in the marine diatom Phaeodactylum tricornutum. Genome Biol. 2015; 16: 102.

PubMed Abstract | Publisher Full Text | Free Full Text | F1000 Recommendation

9. $\quad F$ Berke L, Snel B: The plant Polycomb repressive complex 1 (PRC1) existed in the ancestor of seed plants and has a complex duplication history. $B M C$ Evol Biol. 2015; 15: 44

PubMed Abstract | Publisher Full Text | Free Full Text | F1000 Recommendation

10. F Zhang $\mathrm{X}$, Clarenz $\mathrm{O}$, Cokus $\mathrm{S}$, et al:: Whole-genome analysis of histone $\mathrm{H} 3$ lysine 27 trimethylation in Arabidopsis. PLOS Biol. 2007; 5(5): e129. PubMed Abstract | Publisher Full Text | Free Full Text | F1000 Recommendation

11. Widiez T, Symeonidi A, Luo C, et al:: The chromatin landscape of the moss Physcomitrella patens and its dynamics during development and drough stress. Plant J. 2014; 79(1): 67-81.

PubMed Abstract | Publisher Full Text

12. Jacob $Y$, Feng $S$, LeBlanc CA, et al:: ATXR5 and ATXR6 are H3K27 monomethyltransferases required for chromatin structure and gene silencing. Nat Struct Mol Biol. 2009; 16(7): 763-8. PubMed Abstract | Publisher Full Text | Free Full Text

13. F Okano $\mathrm{Y}$, Aono N, Hiwatashi $\mathrm{Y}$, et al:: A polycomb repressive complex 2 gene regulates apogamy and gives evolutionary insights into early land plan evolution. Proc Natl Acad Sci U S A. 2009; 106(38): 16321-6. PubMed Abstract | Publisher Full Text | Free Full Text | F1000 Recommendation

14. F Mosquna A, Katz A, Decker EL, et al:: Regulation of stem cell maintenance by the Polycomb protein FIE has been conserved during land plant evolution. Development. 2009; 136(14): 2433-44. PubMed Abstract | Publisher Full Text | F1000 Recommendation

15. F Horst NA, Katz A, Pereman I, et al:: A single homeobox gene triggers phase transition, embryogenesis and asexual reproduction. Nat Plants. 2016; 2: 15209.

PubMed Abstract | Publisher Full Text | F1000 Recommendation

16. Horst NA, Reski R: Alternation of generations - unravelling the underlying molecular mechanism of a 165 -year-old botanical observation. Plant Biol (Stuttg). 2016; 18(4): 549-51.

PubMed Abstract | Publisher Full Tex

17. $\mathrm{F}$ Lee $\mathrm{JH}$, Lin $\mathrm{H}$, Joo S, et al.: Early sexual origins of homeoprotein heterodimerization and evolution of the plant KNOX/BELL family. Cell. 2008; 133(5): 829-40.

PubMed Abstract | Publisher Full Text | F1000 Recommendation

18. F Sowpati DT, Ramamoorthy S, Mishra RK: Expansion of the polycomb system and evolution of complexity. Mech Dev. 2015; 138(Pt 2): 97-112. PubMed Abstract | Publisher Full Text | F1000 Recommendation

19. Senthilkumar R, Mishra RK: Novel motifs distinguish multiple homologues of Polycomb in vertebrates: expansion and diversification of the epigenetic toolkit. BMC Genomics. 2009; 10: 549. PubMed Abstract | Publisher Full Text | Free Full Text

20. F Turck F, Roudier F, Farrona S, et al: Arabidopsis TFL2/LHP1 specifically associates with genes marked by trimethylation of histone H3 lysine 27. PLOS Genet. 2007; 3(6): e86.

PubMed Abstract | Publisher Full Text | Free Full Text | F1000 Recommendation

21. Zhang X, Germann S, Blus BJ, et al:: The Arabidopsis LHP1 protein colocalizes with histone $\mathrm{H} 3$ Lys27 trimethylation. Nat Struct Mol Biol. 2007; 14(9): 869-71. PubMed Abstract | Publisher Full Text

22. $\mathrm{F}$ Li Z, Fu X, Wang $\mathrm{Y}$, et al: Polycomb-mediated gene silencing by the $\mathrm{BAH}$ EMF1 complex in plants. Nat Genet. 2018; 50(9): 1254-61. PubMed Abstract | Publisher Full Text | F1000 Recommendation

23. F Qian S, Lv X, Scheid RN, et al:: Dual recognition of H3K4me3 and H3K27me3 by a plant histone reader SHL. Nat Commun. 2018; 9: 2425. PubMed Abstract | Publisher Full Text | Free Full Text | F1000 Recommendation

24. F Yang Z, Qian S, Scheid RN, et al.: EBS is a bivalent histone reader that regulates floral phase transition in Arabidopsis. Nat Genet. 2018; 50(9): 1247-53. PubMed Abstract | Publisher Full Text | F1000 Recommendation

25. F Bowman JL, Kohchi T, Yamato KT, et al.: Insights into Land Plant Evolution Garnered from the Marchantia polymorpha Genome. Cell. 2017; 171(2): 287-304.e15.

PubMed Abstract | Publisher Full Text | F1000 Recommendation

26. F Nishiyama T, Sakayama H, de Vries J, et al:: The Chara Genome: Secondary Complexity and Implications for Plant Terrestrialization. Cell. 2018; 174(2): 448-464.e24.

PubMed Abstract | Publisher Full Text | F1000 Recommendation

27. Hauenschild A, Ringrose L, Altmutter C, et al:: Evolutionary plasticity of polycomb/trithorax response elements in Drosophila species. PLOS Biol. 2008; 6(10): e261

PubMed Abstract | Publisher Full Text | Free Full Text

28. $\mathrm{F}$ Xiao J, Jin R, Yu X, et al.: Cis and trans determinants of epigenetic silencing by Polycomb repressive complex 2 in Arabidopsis. Nat Genet. 2017; 49(10): 1546-52.

PubMed Abstract | Publisher Full Text | F1000 Recommendation

29. $F$ Zhou $Y$, Wang $Y$, Krause $K$, et al:: Telobox motifs recruit CLF/SWN-PRC2 for H3K27me3 deposition via TRB factors in Arabidopsis. Nat Genet. 2018; 50(5): 638-44.

PubMed Abstract | Publisher Full Text | F1000 Recommendation

30. F Yuan W, Luo X, Li Z, et al.: A cis cold memory element and a trans epigenome reader mediate Polycomb silencing of FLC by vernalization in Arabidopsis. Nat Genet. 2016; 48(12): 1527-34. PubMed Abstract | Publisher Full Text | F1000 Recommendation

31. F Yang C, Bratzel F, Hohmann N, et al:: VAL- and AtBMI1-mediated H2Aub initiate the switch from embryonic to postgerminative growth in Arabidopsis. Curr Biol. 2013; 23(14): 1324-9.

PubMed Abstract | Publisher Full Text | F1000 Recommendation

32. F Qüesta Jl, Song J, Geraldo N, et al:: Arabidopsis transcriptional repressor VAL1 triggers Polycomb silencing at FLC during vernalization. Science. 2016 353(6298): 485-8

PubMed Abstract | Publisher Full Text | F1000 Recommendation

33. F Zhou Y, Hartwig B, James GV, et al:: Complementary Activities of TELOMERE REPEAT BINDING Proteins and Polycomb Group Complexes in Transcriptional Regulation of Target Genes. Plant Cell. 2016; 28(1): 87-101. PubMed Abstract | Publisher Full Text | Free Full Text | F1000 Recommendation

34. Schrumpfová PP, Vychodilová I, Dvořáčková M, et al.: Telomere repeat binding proteins are functional components of Arabidopsis telomeres and interact with telomerase. Plant J. 2014; 77(5): 770-81.

PubMed Abstract | Publisher Full Text | Free Full Text

35. F $\quad$ Montero JJ, López-Silanes I, Megías D, et al:: TERRA recruitment of polycomb to telomeres is essential for histone trymethylation marks at telomeric heterochromatin. Nat Commun. 2018; 9(1): 1548 PubMed Abstract | Publisher Full Text | Free Full Text | F1000 Recommendation

36. Vaquero-Sedas MI, Luo C, Vega-Palas MA: Analysis of the epigenetic status of telomeres by using ChIP-seq data. Nucleic Acids Res. 2012; 40(21): e163. PubMed Abstract | Publisher Full Text | Free Full Text

37. $\mathrm{F}$ Jamieson $\mathrm{K}, \mathrm{McNaught} \mathrm{KJ}$, Ormsby $\mathrm{T}$, et al:: Telomere repeats induce domains of H3K27 methylation in Neurospora. eLife. 2018; 7: pii: e31216. PubMed Abstract | Publisher Full Text | Free Full Text | F1000 Recommendation

38. Vrbsky J, Akimcheva S, Watson JM, et al:: siRNA-mediated methylation of Arabidopsis telomeres. PLoS Genet. 2010; 6(6): e1000986. PubMed Abstract | Publisher Full Text | Free Full Text

39. $\mathrm{F}$ Azzalin $\mathrm{CM}$, Reichenbach $\mathrm{P}$, Khoriauli $\mathrm{L}$, et al:: Telomeric repeat containing RNA and RNA surveillance factors at mammalian chromosome ends. Science. 2007; 318(5851): 798-801.

PubMed Abstract | Publisher Full Text | F1000 Recommendation

40. F Tan LM, Zhang CJ, Hou XM, et al:: The PEAT protein complexes are required for histone deacetylation and heterochromatin silencing. EMBO 2018; 37(19): pii: e98770.

PubMed Abstract | Publisher Full Text | Free Full Text | F1000 Recommendation

41. Hohenstatt ML, Mikulski P, Komarynets O, et al:: PWWP-DOMAIN INTERACTOR OF POLYCOMBS1 Interacts with Polycomb-Group Proteins and Histones and Regulates Arabidopsis Flowering and Development. Plant Cell. 2018; 30(1): 117-33.

PubMed Abstract | Publisher Full Text | Free Full Text

42. F Calixto CPG, Guo W, James AB, et al:: Rapid and dynamic alternative splicing impacts the Arabidopsis cold response transcriptome. Plant Cell. 2018; 30(7): 1424-1444.

PubMed Abstract | Publisher Full Text | Free Full Text | F1000 Recommendation 


\section{Open Peer Review}

\section{Current Peer Review Status:}

\section{Editorial Note on the Review Process}

Faculty Reviews are review articles written by the prestigious Members of Faculty Opinions. The articles are commissioned and peer reviewed before publication to ensure that the final, published version is comprehensive and accessible. The reviewers who approved the final version are listed with their names and affiliations.

\section{The reviewers who approved this article are:}

\section{Version 1}

\section{Rakesh K Mishra}

Centre for Cellular and Molecular Biology, Hyderabad, India

Competing Interests: No competing interests were disclosed.

\section{Yuehui He (iD)}

National Key Laboratory of Plant Molecular Genetics, Shanghai Center for Plant Stress Biology, CAS Center for Excellence in Molecular Plant Sciences, Chinese Academy of Sciences, Shanghai, China Competing Interests: No competing interests were disclosed.

The benefits of publishing with F1000Research:

- Your article is published within days, with no editorial bias

- You can publish traditional articles, null/negative results, case reports, data notes and more

- The peer review process is transparent and collaborative

- Your article is indexed in PubMed after passing peer review

- Dedicated customer support at every stage

For pre-submission enquiries, contact research@f1000.com 